\title{
Rearview
}

\section{Towers become the fashionable part of mobile networks}

\author{
A regular column on the information industries
}

Jason Whalley and Peter Curwen

W

hen one thinks of mobile telecommunications, what currently springs to mind are 5G, ever more powerful mobile devices and apps. Probably the last thing that comes to mind are the towers on which the antennas are located - unless they have been burnt down as a cure for COVID-19.

Nevertheless, the size and widespread geographical scope of recent tower deals suggest that towers are worthy of closer examination.

Illustrative examples of recent tower deals are provided in Table 1. The largest of these deals, at more than $€ 5,200 \mathrm{~m}$, involves Vodafone. In July 2019, Vodafone announced that it would be merging its Italian towers business with an affiliate of Telecom Italia. Vodafone would receive a large minority stake in the merged company, as well as €2,140m in cash. The merger is yet to be completed, with regulatory approval expected to be gained in the second quarter of 2020. Just a few days after the merger in Italy was announced, it emerged that Vodafone had created a dedicated company to manage more than 61,000 towers across
Europe. These towers, which are mainly to be found in four large markets - Germany, Italy, Spain and the UK - generate annual revenues of roughly $€ 1,700 m$ and EBITDA of $€ 900 \mathrm{~m}$.

Vodafone is not alone in seeing value in its tower operations. In late 2019,

Telefónica, which owned 68,000 towers at the time across a dozen countries, asked consultants to explore how it could "monetise" these assets. In early 2020, this began with the sale of towers in Brazil, Colombia and Ecuador for a combined total of $€ 640 \mathrm{~m}$. While Orange has sold its Spanish tower operations to Cellnex for €260m, it seems less willing to sell its towers than other operators - it is creating tower companies in other countries but stated its intention to retain control of them. As a consequence, mergers rather than outright sales by Orange seem more likely at the moment.

In June 2018, Altice, a heavily indebted French telco, announced its intentioned to raise as a much as $€ 2,500 \mathrm{~m}$ from the sale of its tower operations. To this end, Altice sold all of its towers in the Dominican
Jason Whalley is based at Newcastle Business School, Northumbria University, Newcastle upon Tyne, UK. Peter Curwen is Independent Scholar, Leeds, UK. 
Republic and a majority stake in its Portuguese tower business in late 2018. It also sold a $49.99 \%$ stake in its French tower subsidiary to KKR, which valued the entire business at $€ 3,600 \mathrm{~m}$. More recently, the tower business in Portugal, in which Altice retained a minority stake, was acquired by Cellnex for $€ 800 m$. And Cellnex has also acquired the tower operations of Iliad, another highly indebted French operator, in France and Italy for a combined total of $€ 2,000 \mathrm{~m}$.

But why are mobile operators currently so interested in disposing of their towers? One explanation is that the operators need the money. The mobile industry is a capital-intensive business, in part because of the emergence of a new generation of technology every decade or so and partly due to consumers who expect coverage everywhere they go. In addition, some operators have borrowed substantial sums to fund their (rapid) domestic and international expansion. The end result is that many operators are carrying a large amount of debt Altice Europe, for example, ended 2018 with gross debts of $€ 32,462 m$ supported by businesses generating EBITDA of $€ 5,101 \mathrm{~m}$. The sale of its tower operations to date have provided Altice with around $€ 2,500 \mathrm{~m}$ in fresh funds, enabling it to invest in those businesses that it has retained as well as reducing its debt burden.

Another explanation is value creation. Mobile operators have long argued that they are worth more than their current stock market valuations. The sale of towers has provided mobile operators with a way to demonstrate this. When Vodafone announced that it had brought together its towers across Europe into a single company, analysts estimated that it would be worth somewhere between $€ 15 b n$ and $€ 20 b n$ if it is was spun-off as a separate business. This compares favourably with the $€ 19 b n$ it spent on the acquisition of the cable operations of Liberty Global which was given regulatory approval in the same month, Vodafone's stock market value at the time (£35bn/€38.8bn) and the company's net debt in March 2018 (€31.5bn).

Table 1 Hints at a further explanation: the emergence of companies focusing on towers such as American tower corporation (ATC), phoenix tower international and Cellnex. As these companies are not tied to a single mobile operator, more than one can use each tower. Not only does this speed up the pace at which an operator can rollout their services, it also reduces the need for more towers to be built. Through allowing several operators to occupy a tower, operators can provide coverage in areas, such as those that are rural and remote or with limited demand, where previously it would have been uneconomic to do so. When these benefits are combined with the desire of operators to focus on other parts of their business, it is arguably no surprise that some tower companies have rapidly grown in recent years - phoenix tower international now operates 86,000

Table 1 Illustrative tower deals, 2018 to 2020

\begin{tabular}{|c|c|c|c|c|c|c|}
\hline Year & Country & Buyer & Target & $\begin{array}{l}\text { Value } \\
\text { million }\end{array}$ & $\begin{array}{c}\text { No. } \\
\text { of sites }\end{array}$ & $\begin{array}{c}\text { Price } \\
\text { per tower }\end{array}$ \\
\hline 2018 & India & American Tower Corp. & Vodafone India & $\$ 592$ & 10,200 & $\$ 58,039$ \\
\hline 2018 & Jamaica & Phoenix Tower Int'l & Digicel Jamaica & $\$ 90$ & 451 & $\$ 199,556$ \\
\hline 2018 & Portugal & M. Stanley Infrastructureet al. & Altice Europe & $€ 660$ & 2,961 & $€ 222,898$ \\
\hline 2018 & Dominican Republic & Phoenix Tower Int'l & Altice Europe & $\$ 145$ & 1,039 & $\$ 139,557$ \\
\hline 2018 & France & KKR & Altice Europe & $€ 3,600$ & 10,198 & $€ 353,010$ \\
\hline 2019 & Italy & INWIT SpA & Vodafone Italy Towers & $€ 5,270$ & 22,100 & $€ 238,461$ \\
\hline 2019 & Bolivia & Phoenix Tower Int'l & Viva & $\$ 100$ & 600 & $\$ 166,666$ \\
\hline 2019 & India & Brookfield Infrastructure & Reliance Jio Infratel & $\$ 3,600$ & 130,000 & $\$ 27,692$ \\
\hline 2019 & $\begin{array}{l}\text { Colombia, Mexico, } \\
\text { Nicaragua }\end{array}$ & Phoenix Tower Int'l & Uniti Group & $\$ 100$ & 500 & $\$ 200,000$ \\
\hline 2019 & Spain & Cellnex & Orange España & $€ 260$ & 1,500 & $€ 173,333$ \\
\hline 2019 & UK & Cellnex & Arqiva & $£ 2,000$ & 7,400 & $£ 270,270$ \\
\hline 2019 & France & Cellnex & Iliad Group & $€ 1,400$ & 5,700 & $€ 245,614$ \\
\hline 2019 & Italy & Cellnex & Iliad Group & $€ 600$ & 2,200 & $€ 272,727$ \\
\hline 2019 & Africa & American Tower Corp. & Eaton Towers Holdings & $\$ 1,850$ & 5,700 & $\$ 324,561$ \\
\hline 2020 & Brazil & Telxius Torres Brasil & Telefónica Brasil & $\$ 148.3$ & 1,909 & $\$ 77,684$ \\
\hline 2020 & $\begin{array}{l}\text { Ecuador and } \\
\text { Colombia }\end{array}$ & Phoenix Tower Int'l & Telefónica & $\$ 325$ & 2,029 & $\$ 160,171$ \\
\hline 2020 & Portugal & Cellnex & Nos Towering & $€ 375$ & 2,000 & $€ 187,500$ \\
\hline 2020 & Portugal & Cellnex & Altice Europe et al. & $€ 800$ & 3,000 & $€ 266,666$ \\
\hline
\end{tabular}

Source: Compiled by the authors from various articles published by TeleGeography and the Financial Times, as well as the press releases and annual reports of Altice Europe, Uniti Group and Vodafone 
towers across 14 countries whereas Cellnex owns 50,000 towers in six European countries. The expansion of Cellnex is relatively recent, having acquired almost 22,000 towers in five countries over the course of the last two years.

A key issue in the above is the valuation of a tower. By dividing the value of transactions by the number of towers involved, some light can be shed on this question. From Table 1 it can be seen that the prices paid for towers in emerging markets are less than those paid in Europe, which is perhaps unsurprising. What is surprising, however, is the difference in prices paid by ATC and Brookfield Infrastructure Partners in India - the former paid twice as much as the latter. This difference may reflect a whole host of factors such as where the towers are located, their potential to generate (new) revenue and how much subsequent investment is needed.

It is also noticeable that the price per tower paid by ATC when it acquired Eaton Towers is considerably higher than the other prices paid in emerging markets. This may, however, reflect the strategic nature of the purchase that expanded ATC's footprint across Africa and positioned it for further deals. While ATC has focused on towers since just after the turn of the millennium, its expansion over the past decade has been particularly rapid. Through sustained deal making since 2010, ATC has entered 15 countries spread across Africa, Europe and Latin America. As it has entered these markets, the number of towers that ATC operates has considerably increased, reaching 180,000 by the end of 2019 . The bulk of these towers are, however, located in just two markets: India $(75,000)$ and the United States $(41,000)$.

Across Europe prices range from $€ 173,000$ to $€ 353,000$ per tower, with no discernible pattern emerging. This may reflect the quality of the assets being sold, but it could equally well reflect the desperation of the seller. As Altice has sold various businesses and raised funds, the financial pressures that it faces have eased with the consequence that it appears to have been able to extract better terms more recently from buyers than was initially the case.

The sale of towers is currently providing mobile operators with a way to raise much needed capital, to pay down debt and perhaps even return some to their shareholders. However, it can only be viewed as a one-off solution to the challenges that operators face. Fortunately, perhaps, the one thing that consumers are unwilling to do is cut back on communications in the face of COVID-19. On the other hand, they are increasingly doing this via OTT services such as WhatsApp, Skype and the like.

\section{Corresponding author}

Jason Whalley can be contacted at: jason.whalley@northumbria.ac.uk 